\title{
PERAN MEDIASI MINAT BELI PADA PENGARUH BRANDAMBASSADOR DAN KUALITAS PRODUK TERHADAP KEPUTUSAN PEMBELIAN
}

\author{
${ }^{1)}$ Liza Kharisma, ${ }^{2}$ Saidun Hutasuhut \\ $\left.{ }^{1}\right)$ Alumni Fakultas Ekonomi, Universitas Negeri Medan, Medan \\ kharismasakura@gmail.com \\ 2) Fakultas Ekonomi Universitas Negeri Medan, Medan \\ saidun@unimed.ac.id
}

\begin{abstract}
Abstrak
Penelitian ini bertujuan untuk mengetahui peran mediasi minat beli pada pengaruh brand ambassador dan kualitas produk terhadap keputusan pembelian pelanggan Medan Napoleon. Jumlah populasi dalam penelitian ini adalah seluruh konsumen Medan Napoleon. Responden sebanyak 105 orang responden. Teknik pengumpulan data digunakan kuesioner. Data dianalisis dengan menggunakan analisis jalur (path analysis) dan hipotesis dengan uji " $\mathrm{t}$ ". Hasil penelitian menunjukkan bahwa (1) Terdapat pengaruh positif dan signifikan brand ambassadorterhadap minat beli. (2) Terdapat pengaruh positif dan signifikan kualitas produk terhadap minat beli. (3) terdapat pengaruh positif dan signifikan brand ambassadorterhadap keputusan pembelian. (4) kualitas produk tidak berpengaruh terhadap keputusan pembelian. (5) Terdapat pengaruh yang positif dan signifikan minat beli terhadap keputusan pembelian. (6) Terdapat peran mediasi minat beli pada pengaruh brand ambassador terhadap keputusan pembelian. (7) Terdapat peran mediasi minat beli pada pengaruh kualitas produk terhadap keputusan pembelian. Perusahaan dapat meningkatkan omzet penjualan melalui penggunaan brand ambassadorn dan menjaga kualitas produk agar minat beli konsumen meningkat dan melakukan keputusan pembelian.
\end{abstract}

Kata Kunci: Brand Ambassador, Kualitas Produk, Minat Beli, dan Keputusan Pembelia 


\section{PENDAHULUAN}

Sepuluh tahun terakhir usaha kuliner mengalami kemajuan yang cukup pesat. Pada tahun 2013, nilai tambah industri kuliner mencapai Rp 208,63 triliun. Jumlah tersebut menyumbang $32,5 \%$ terhadap total PDB sektor ekonomi kreatif yang sebesar Rp 641,8 triliun (sumber: tribunnews.com). Usaha sektor makanan dan minuman ini, mampu memberikan kontribusi tertinggi dengan pertumbuhannya sebesar $12,7 \%$ pada tahun 2018 (Trihendrawan, Nuriwan, 2019). Usaha sektor makanan dan minuman diantaranya termasuk bisnis roti dan kue. Bisnis ini di Indoensia bertumbuh $8 \%$ pada tahun 2017 (Kontan.co.id 30 Januari 2018).

Pelaku bisnis ini $60 \%$ usaha tradisional UMKM, 20\% produsen besar, sisanya $12 \%$ ialah produsen roti artisan (RadarBandung 13 November 2019). Banyaknya peminat bisnis kuliner membuat persaingan sesama usaha semakin ketat.

Pada situasi pesaingan yang kompetitif konsumen bebas memilih produk yang diinginkan dari berbagai penjual. Konsumen semakin cermat dan pintar dalam memilih setiap produk yang tersedia di pasar. Banyak hal yang menjadi bahan pertimbangan dan harapan berbeda dari perilaku konsumen mengenai produk kuliner yang akan dibeli. Mereka dapat memperolehnya dan hal apa saja yang dapat menarik konsumen untuk melakukan keputusan pembelian. Persaingan bisnis kuliner semakin ketat menuntut setiap perusahaan dapat menciptakan keunggulan kompetitif yang berkesinambungan agar dapat memenangkan persaingan.

Usaha Bakery, cake, dan pastry di Indonesia terutama di kota besar seperti Jakarta, Bandung, Surabaya dan Medan sudah menjadi lifestyle. Salah satu usaha Bakery, cake, dan pastry yang ada di kota Medan adalah Medan Napoleon yang dimiliki artis Irwansyah. Medan Napoleon adalah salah satu merk atau brand kuliner baru di kota Medan yang dimiliki artis Irwansyah. Medan Napoleon hadir sebagai salah satu pilihan baru kuliner Medan di bidang oleholeh.Sebagaimana oleh-oleh khas Medan lainnya, Medan Napoleon juga merupakan cake yang diadaptasi dari negeri Eropa. Dengan kreasi dan olahan tangan dingin chef professional, Medan Napoleon hadir sebagai oleh-oleh dengan karakteristik unik yang baru ada di Medan. Medan Napoleon disebut sebagai kue oleh-oleh baru yang halal dan kekinian dari kota Medan. Produk Medan Napoleon sendiri berupa cake dengan karakteristik unik sesuai dengan ciri masyarakat Medan.Cake dengan lapisan puff pastry ditengahnya dibalut dengan sofcake lembut. 
Bahan-bahan baku Medan Napoleon menggunakan bahan lokal terutama durian yang menjadi andalan Medan Napoleon serta varian favorit lainnya. Penggunaan bahan-bahan lokal menjadikan sajian Medan Napoleon selalu fresh from the oven dan sehat karena tanpa bahan pengawet.(sumbermedannapoleon.com.
Akan tetapi ketatnya persaingan usaha ini juga dialami Medan Napoleon dan omset penjualan mereka mengalami fluktuasi periode 2016-2018. Rating usaha Medan Napoleon masih berada pada peringkat 7 dari 10 usaha sejenis yang ada di kota Medan seperti dijelaskan pada Tabel 1.

Tabel 1 Daftar Toko Kue di Medan Tahun 2018

\begin{tabular}{|r|l|c|}
\hline \multicolumn{1}{|c|}{ No } & \multicolumn{1}{|c|}{ Nama Toko Kue } & Rating (1-5) \\
\hline 1. & Mawar Bakery \& Cake Shop & 4,5 \\
\hline 2. & Aroma Bakery \& Cake Shop & 4,4 \\
\hline 3. & Phin-phin & 4,3 \\
\hline 4. & Majestyk Bakery \& Cake Shop & 4,2 \\
\hline 5. & Clover Bake Shop & 4,1 \\
\hline 6. & Hera Modern Bakery \& Cake & 4,0 \\
\hline 7. & Medan Napoleon & 3,8 \\
\hline 8. & Rumah Kue Salsabila & 3,5 \\
\hline 9. & Choco Bakery & 3,3 \\
\hline 10 & Jofie Bakery \& Cake Shop & 3,0 \\
\hline
\end{tabular}

Sumber : Bacaterus.com

Jika perusahaan ingin tetap eksis dituntut harus lebih aktif dan kreatif dalam melakukan pemasaran dan penjualan produknya. Banyak hal yang dapat dilakukan untuk memenangkan persaingan. Salah satu cara yang dapat dilakukan adalah membangun brand image. Brand image dapat dibangun dengan menggunakan Brand Ambassador. Putra M. I. (2014) menyatakan brand ambassasor dapat mempengaruhi brand image. Brand ambassador biasanya menggunakan para artis terkenal karena memiliki penggemar yang cukup besar. Biasanya penggemar cenderung mengikuti apa yang dilakukan artis pujaanya. Kalau artis pujaan menggunakan suatu produk penggemar juga berkeinginan menggunakan produk tersebut. Hafilah, E., Chaer, V., \& Usman, O. (2019) menyatakan bahwa penggunaan brand ambassador dapat mempengaruhi keputusan pembelian konsumen.

Strategi penting lain yang dapat digunakan perusahaan untuk menarik minat konsumen adalah menawarkan produk berkualitas. Tjiptono (2000:4) menyatakan kualitas adalah suatu kondisi dinamis 
yang berhubungan dengan produk dan jasa, manusia, proses dan lingkungan yang memenuhi atau melebihi harapan. Sedangkan menurut Kotler (2007:180) kualitas adalah keseluruhan ciri serta sifat barang dan jasa yang berpengaruh pada kemampuan memenuhi kebutuhan. Lebih spesifik kualitas produk kue terkait dengan bahan yang digunakan, bentuk, dan rasa. Konsumen akan membeli suatu produk apabila dianggap kualitasnya memenuhi kebutuhan. Saidani, B., \& Arifin, S. (2012); Silvana\& Hutasuhut (2017) menemukan kualitas produk bepengaruh terhadap konsumen untuk membeli produk. Lebih lanjut Saidani, B., \& Arifin, S. (2012) juga menyatakan bahwa kualitas produk berpengaruh terhadap minat beli.

Penggunaan brand ambassador diharapkan dapat mempengauhi minat calon konsumen untuk

\section{TINJAUAN PUSTAKA}

\section{Keputusan Pembelian}

Keputusan pembelian konsumen terhadap suatu produk pada dasarnya erat kaitannya dengan perilaku konsumen. Perilaku konsumen merupakan unsur penting dalam kegiatan pemasaran suatu produk yang perlu diketahui oleh perusahaan, karena perusahaan pada dasarnya tidak mengetahui mengenai apa yang ada dalam fikiran seorang konsumen pada waktu sebelum, membeli suatu produk. Ningrum, N. S. (2017); Cece, I. S. (2015) menyatakan brand abassador mempengaruhi minat beli konsumen.Selanjutnya Septifani, R., Achmadi, F., \& Santoso, I. (2014) menyatakan bahwa minat konsumen mempengaruhi seseorang untuk membeli. Penelitian menguji pengaruh langsung brand ambassador dan kualitas produk terhadap minat dan keputusan pembelian telah banyak dilakukan. Selanjutnya pengaruh langsung minat beli terhadap keputusan pembelian juga sudah diteliti sebelumnya. Akan tetapi peran mediasi minat beli pada pengaruh brand ambassador dan kualitas produk terhadap keputusan pembelian masih perlu dilakukan dan apakah mediasi minat beli menambah kuat keputusan konsumen untuk membeli.

sedang, dan setelah melakukan pembelian produk tersebut.

Adanya kecenderungan pengaruh kualitas produk, dan brand terhadap keputusan pembelian yang dilakukan oleh konsumen tersebut, mengisyaratkan bahwa manajemen perusahaan perlu mempertimbangkan aspek perilaku konsumen, terutama proses pengambilan keputusan pembeliannya. Inti dari keputusan pembelian konsumen adalah bagaimana mengintegrasikan 
pengetahuan untuk mengevaluasi beberapa alternatif, dan memilih salah satu diantaranya". Hasil dari proses pengintegrasian adalah berupa pilihan yang dituangkan secara kognitif sebagai keinginan berprilaku.

Penjual perlu menyusun struktur keputusan pembelian secara keseluruhan untuk membantu konsumen dalam mengambil keputusan tentang pembeliannya. etiap konsumen membeli mempunyai struktur sebanyak tujuh. Dimensidimensi tersebut menurut Danang Sunyoto, (2014:283) :

1) Keputusan tentang jenis produk. Konsumen dapat mengambil keputusan untuk membeli sebuah produk. Dalam hal ini perusahaan harus memusatkan perhatiannya kepada orangorang yang berminat membeli suatu produk serta alternatif lain yang mereka pertimbangkan.

2) Keputusan tentang bentuk produk. Keputusan ini menyangkut ukuran, mutu, corak dan sebagainya. Dalam hal ini perusahaan harus melakukan riset pemasaran untuk mengetahui kesukaan konsumen tentang produk bersangkutan agar dapat memaksimumkan daya tarik mereknya.

3) Keputusan tentang merek. Konsumen harus mengambil keputusan tentang merek mana yang akan dibeli. Setiap merek memiliki perbedaan-perbedaan sendiri. Dalam hal ini perusahaan harus mengetahui bagaimana konsumen memilih sebuah merek.

4) Keputusan tentang penjualnya. Konsumen harus mengambil keputusan dimana produk tersebut akan dibeli. Dalam hal ini produsen, pedagang besar, dan pengecer baru mengetahui bagaimana konsumen memilih sebuah merek.

5) Keputusan tentang jumlah produk. Konsumen dapat mengambil keputusan tentang seberapa banyak produk yang akan dibelinya pada suatu saat. Dalam hal ini perusahaan harus mempersiapkan banyaknya produk sesuai dengan keinginan yang berbeda-beda dari para pembeli.

6) Keputusan tentang waktu pembelian. Konsumen dapat mengambil keputusan tentang kapan ia harus melakukan pembelian. Masalah ini akan menyangkut adanya uang. Oleh karena itu, perusahaan harus mengetahui keputusan konsumen dalam penentuan waktu pembelian.

7) Keputusan tentang cara pembayaran. Konsumen harus mengambil keputusan tentang metode atau cara pembayaran produk yang akan dibeli. Keputusan tersebut akan mempengaruhi keputusan tentang penjual dan jumlah pembeliannya. 
Dalam hal ini perusahaan harus mengetahui keinginan pembeli terhadap cara pembayarannya.

\section{Brand Ambassador}

Untuk membangun kepercayaan pada konsumen terhadap produk yang ditawarkan, setiap perusahaan harus menciptakan strategi pemasaran langsung yang dapat mempengaruhi konsumen akan suatu produk, perusahaan dapat menggunakan public figure sebagai Brand Ambassador sebagai promosi dalam memasarkan produknya. Penggunaan brand abassador tentunya konsumen akan lebih tertarik terhadap produk yang di gunakan oleh public figure yang dapat mempengaruhi keputusan pembeliannya terhadap suatu produk.

Pengertian brand ambassador menurut Lea Greenwood (2012:88), "Brand ambassador is a tool used by companies to communicate and connect with the public, regarding how them actually enchances sales". Brand ambassador adalah alat yang digunakan oleh perusahaan untuk berkomunikasi dan terhubung dengan public, dan bagaimana mereka memanfaatkan penjual. Brand ambassador merupakan upaya yang dilakukan perusahaan untuk mempengaruhi atau mengajak konsumen dengan menggunakan selebrity sebagai ikon untuk mempresentasikan citra terbaik dari suatu produk, agar konsumen tertarik untuk menggunakan produk tersebut.

\section{Kualitas Produk}

Menurut Kotler dan Amstrong (2008:272) kualitas produk sebagai karakteristik produk atau jasa yang bergantung pada kemampuannya untuk memuaskan kebutuhan pelanggan yang dinyatakan atau diimplikasikan.Kualitas produk adalah salah satu sarana positioning utama pemasar. Kemudian Mowen dan Michael (2002:93) mendefinisikan kualitas produk sebagai evaluasi menyeluruh pelanggan atas kebaikan kinerja barang atau jasa.

Kualitas suatu produk makanan sangatlah penting bagi setiap pendiri perusahaan penjual makanan, karena menurut Potter dan Hotchkiss (1995:90-112 dalam Margaretha dan Edwin 2012) food quality adalah karakteristik kualitas dari makanan yang dapat diterima oleh konsumen. Ini termasuk dalam faktor eksternal seperti ukuran, bentuk, warna, konsistensi, tekstur, dan rasa.Sedangkan West, Wood dan Harger (1965 dalam Fiani, S. Margaretha dan Edwin 2012) juga menyatakan bahwa standar food quality, meskipun sulit didefinisikan dan tidak dapat diukur secara mekanik, masih dapat dievaluasi lewat nilai nutrisinya, tingkat bahan yang digunakan, rasa, dan penampilan dari produk.

Kotler dan Keller (2007:9) mengemukakan 6 dimensi kualitas produk yang perlu diperhatikan 
yaitu: (1) Mutu kinerja (performance), (2) Keandalan (reliability),(3) Keistimewaan (feature),(4) Daya tahan (durability),(5) Mutu kesesuaian (conformance quality),dan (6) Gaya (style), Menurut West, Wood dan Harger (2006:39), Gaman dan Sherrington (1996:132) serta Jones ( 2000:109-110) dalam jurnal Fiani, S. Margaretha dan Edwin Japarianto. (2012) secara garis besar menjelaskan faktor-faktor yang mempengaruhi food quality adalah : (1) warna, (2) penampilan, (3) porsi, (4) bentuk, (5) temperature, (6) aroma, (7) tingkat kematangan, dan (8) rasa.

\section{Minat Beli}

Menurut Kotler dan Keller (2009) minat beli merupakan

\section{METODE PENELITIAN}

Penelitian ini kuantitaitf ini dilakukan di Medan Napoleon yang berlokasi dijalan K.H.Wahid Hasyim No. 35 Babura, Medan Baru, Kota Medan, Sumatera Utara 20154. Populasi dalam penelitian ini adalah seluruh konsumen yang membeli di Medan Napoleon jalan K.H.Wahid Hasyim. Menurut Ferdinand (2002:48) jumlah sampel dapat ditentukan dengan mengalikan jumlah indikator variabel laten dengan angka 5 - 10. Maka jumlah sampel penelitian sebesar $21 \times 5=$ 105. Sampel ditentukan secara pernyataan mental dari konsumen yang merefleksikan rencana pembelian sejumlah merek tertentu yang menjadi dasar pemilihan sesuatu, minat membeli menunjukkan pada kecenderungan untuk lebih menyukai produk dengan merek tertentu.Keputusan untuk membeli dipengaruhioleh nilai produk yang dievaluasi.Bila manfaat yang dirasakan lebih besar dibandingkan pengorbanan untuk mendapatkannya, maka dorongan untuk membelinya semakin tinggi.Sebaliknya bila manfaatnya lebih kecil dibandingkan pengorbanannya makabiasanya pembeli akan menolak untuk membeli dan pada umumnya beralih mengevaluasi produk lain yang sejenis.

insidental dengan syarat bukan pembelian pertama.

Angket digunakan untuk mengumpulkan data. Angket terlebih dahulu dilakukan uji vadilitas dan uji reliabilitas. Uji asumsi klasik yang digunakan meliputi; uji normalitas, uji linearitas, uji heteroskedastisitas, dan uji multikolinearitas. Teknik analisis data yang digunakan adalah analisis jalur yaitu untuk melihat pengaruh langsung dan pengaruh tidak langsung antara variabel terkait. Uji hipotesis dengan uji $\mathrm{t}$ (parsial). Besarnya pengaruh 
langsung dilihat dari Standardized Coefficients Beta.

Persamaan struktural

penelitian dibangun sebagai berikut:

$Z=\rho_{\mathrm{ZX} 1} \mathrm{X}_{1}+\rho_{\mathrm{ZX} 2} \mathrm{X}_{2}+\varepsilon_{1}$

$\mathrm{Y}=\rho_{\mathrm{YX} 1} \mathrm{X}_{1}+\rho_{\mathrm{YX} 2} \mathrm{X}_{2}+\rho_{\mathrm{YZ}} \mathrm{Z}+\varepsilon_{2}$

Dimana :

$\mathrm{X}_{1}=$ Brand Ambasador

$\mathrm{X}_{2}=$ Kualitas Produk

$\mathrm{Z}=$ Minat Beli

$\mathrm{Y}=$ Keputusan Pembelian

$\varepsilon=$ variabel redisual

$P z X 1=$ Koefisien regresi brand ambassador terhadap minat beli

$P_{Z_{3} X_{2}}=$ Koefisien regresi kualitas produk terhadap minat beli

$P_{Y X_{1}}=$ Koefisien regresi brand ambassador terhadap keputusan pembelian
$P_{Y X_{2}} \quad=$ Koefisien regresi kualitas produk terhadap keputusan pembelian $P_{Y X_{3}}=$ Koefisien regresi minat beli terhadap keputusan pembelian

Kriteria pengujian hipotesis adalah:

Ho : $\beta_{1}=\beta_{2}=0$ artinya variabel bebas $\left(\mathrm{X}_{1}, \mathrm{X}_{2}, \mathrm{Z}\right)$ tidak mempunyai pengaruh yang signifikan terhadap variabel terikat (Y2).

Ha : $\beta_{1} \neq \beta_{2} \neq 0$ artinya variabel bebas $\left(\mathrm{X}_{1}, \mathrm{X}_{2}, \mathrm{Z}\right)$ memiliki pengaruh yang signifikan terhadap variabel terikat (Y2).

Kriteria pengambilan keputusan :

Menolak Ho jika $t_{\text {hitung }}>t_{\text {tabel, }}$, pada $\alpha$ $=5 \%$, atau $\operatorname{Sig}<\alpha=0,05$

MenolakHa jika thitung $<t_{\text {tabel, }}$, pada $\alpha$ $=5 \%$, atau Sig $>\alpha=0,05$. Untuk mempermudah dalam mengolah data digunakan bantuan SPSS

Versi 23.

\section{HASIL DAN PEMBAHASAN}

\section{HASIL}

Hasil uji validitas dan uji reliablitas angket sebagai prasyarat angker disajikan pada Tabel 2.

Tabel 2 Hasil Uji Validitas dan Reliablitas Instrumen

\begin{tabular}{lccccccc}
\hline \multirow{2}{*}{ Variabel } & $\begin{array}{c}\text { Jumlah } \\
\text { Item }\end{array}$ & \multicolumn{2}{c}{ Validitas } & $\begin{array}{c}\text { Keteran } \\
\text { gan }\end{array}$ & Reliabilitas & $\begin{array}{c}\text { Keteran } \\
\text { gan }\end{array}$ \\
\cline { 3 - 7 } & & $\begin{array}{c}\text { Pearson } \\
\text { Correlation }\end{array}$ & Kriteria & & $\begin{array}{c}\text { Coeffic } \\
\text { ient }\end{array}$ & Criteria & \\
\hline $\begin{array}{l}\text { Brand } \\
\text { Ambassador }\end{array}$ & 8 & $0,543-0,806$ & 0,30 & valid & 0,788 & 0,60 & reliabel \\
$\begin{array}{l}\text { Kualitas } \\
\text { produk }\end{array}$ & 12 & $0,368-0,936$ & 0,30 & valid & 0,901 & 0,60 & reliabel \\
$\begin{array}{l}\text { Minat Beli } \\
\text { Keputusan }\end{array}$ & 8 & $0,633-0,801$ & 0,30 & valid & 0,885 & 0,60 & reliabel \\
Pembelian & 14 & $0,396-0,728$ & 0,30 & valid & 0,866 & 0,60 & reliabel \\
\hline
\end{tabular}


Semua instrumen yang diujikan dari ke empat variabek memenuhi syarat validitas dan syarat reliablitas. Selanjutnya hasil uji normalitas data dengan menggunakan Kolmogorov
Smirnov dari ke-empat variabel semua memenuhi syarat karena Asymp. Sig. (2-tailed) semuanya> 0,05 (disajikan pada Tabel 3).

Tabel 3 Uji Kolmogorov Smirnov

One-Sample Kolmogorov-Smirnov Test

\begin{tabular}{|c|c|c|c|c|c|}
\hline & & $\begin{array}{c}\text { Brand } \\
\text { Ambassador }\end{array}$ & $\begin{array}{l}\text { Kualitas } \\
\text { Produk }\end{array}$ & $\begin{array}{l}\text { Minat } \\
\text { Beli }\end{array}$ & $\begin{array}{l}\text { Keputusan } \\
\text { Pembelian }\end{array}$ \\
\hline \multicolumn{2}{|l|}{$\mathrm{N}$} & 105 & 105 & 105 & 105 \\
\hline \multirow{2}{*}{$\begin{array}{l}\text { Normal } \\
\text { Parameters }{ }^{\mathrm{a}, \mathrm{b}}\end{array}$} & Mean & 27.69 & 40.90 & 28.42 & 48.34 \\
\hline & Std. Deviation & 4.382 & 5.621 & 4.089 & 6.174 \\
\hline \multirow{3}{*}{$\begin{array}{l}\text { Most Extreme } \\
\text { Differences }\end{array}$} & Absolute & .075 & .055 & .073 & .043 \\
\hline & Positive & .075 & .038 & .073 & .037 \\
\hline & Negative & -.051 & -.055 & -.046 & -.043 \\
\hline \multicolumn{2}{|c|}{ Kolmogorov-Smirnov Z } & .075 & .055 & .073 & .043 \\
\hline \multicolumn{2}{|c|}{ Asymp. Sig. (2-tailed) } & $.168^{\mathrm{c}}$ & $.200^{\mathrm{c}, \mathrm{d}}$ & $.200^{\mathrm{c}, \mathrm{d}}$ & $.200^{\mathrm{c}, \mathrm{d}}$ \\
\hline
\end{tabular}

Selanjutnya hasil uji tersebar dan tidak ada membentuk heteroskedastisitas menggunakan pola tertentu (disajikan pada Gambar scatterplot dapat diketahui data 1). Jadi model regresi dalam penelitan terbebas dari penelitian ini dapat digunakan. heteroskedastisitas karena data

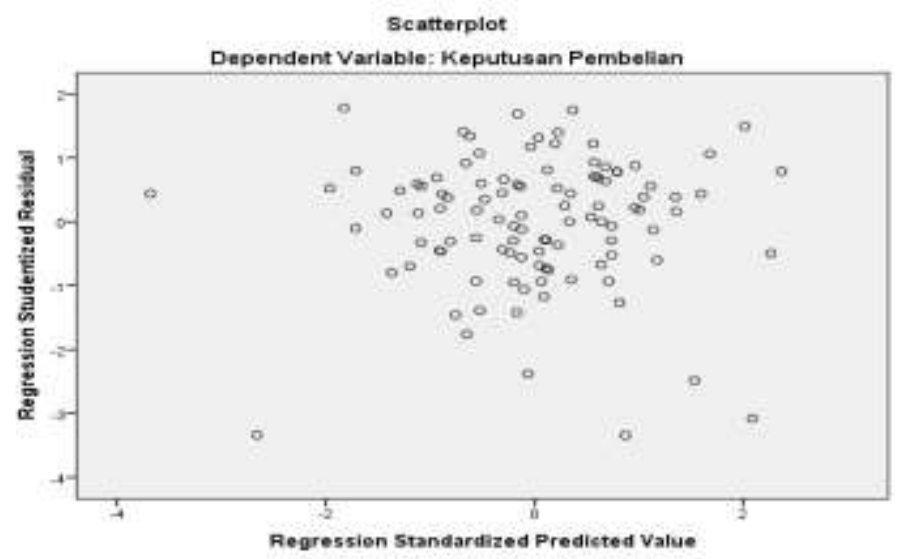

Gambar 1 Hasil Uji Heteroskedastisitas

Prasyarat asumsi klasik Hasil uji disajikan pada Tabel 4 dan berikutnya adalah multikolieneritas. tidak ditemukan adanya 
multikolineiritas antar variabel bebas atas 0,10 dan nilai VIF di bawah 10 . karena nilai tolerance semuanya di

Tabel 4Uji Multikolinearitas Data Struktural I dan Struktural II

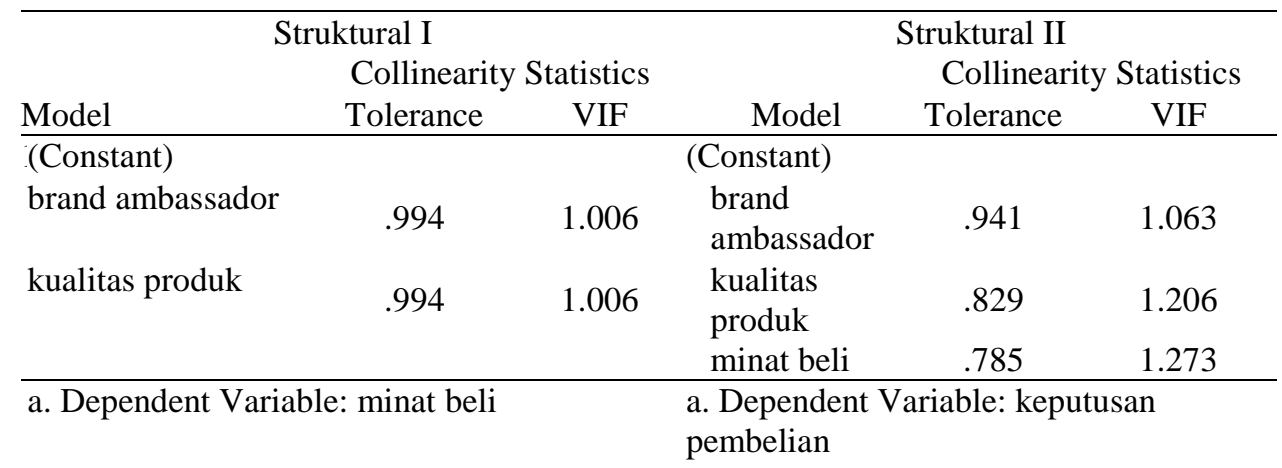

Uji prasyarat asumsi klasik selanjutnya yang dilakukan adalah uji linieritas dan hasilnya disajikan pada Tabel 5. Dilihat dari nilai FLinierity ke-lima pasang data pengaruh variabel prediktor terhadap variabel terikat semuanya di bawah 0,05. Jika lihat juga nilai F-Deviation Tabel 5 Rangkuman Hasil Uji Linearitas

Tabel 5 Uji Linieritas

\section{Analisis Jalur}

Dalam penelitian ini, terdapat dua persamaan struktural. Hasil perhitungan persamaan struktur I
From Linearity juga memenuhi kriteria karena nilainya di atas 0,05 kecuali variabel minat beli (Z) terhadap Keputusan pembelian 0,01 di bawah 0,05. Hal ini tetap dianggap layak karena nilai f-Deviation sudah memenuhi syarat.

\begin{tabular}{llll}
\hline Variabel & $\begin{array}{l}\mathrm{F} \\
\text { Lineer } \\
\text { ity }\end{array}$ & $\begin{array}{l}\text { F-Deviation } \\
\text { From } \\
\text { Linearity }\end{array}$ & $\begin{array}{l}\text { Ketera- } \\
\text { ngan }\end{array}$ \\
\hline $\mathrm{X}_{1} \rightarrow \mathrm{Z}$ & 0,012 & 0,210 & Linear \\
$\mathrm{X}_{2} \rightarrow \mathrm{Z}$ & 0.000 & 0,62 & Linear \\
$\mathrm{X}_{1} \rightarrow \mathrm{Y}$ & 0,000 & 0,265 & Linear \\
$\mathrm{X}_{2} \rightarrow \mathrm{Y}$ & 0,016 & 0,659 & Linear \\
$\mathrm{Z} \rightarrow \mathrm{Y}$ & 0,000 & 0,010 & Linear \\
\hline
\end{tabular}

disajikan pada Tabel 6 dan hasil perhitungan struktural II disajikan pada Tabel 7.

Tabel 6 Coefficients Sub Struktural I 


\begin{tabular}{lrrrr|r}
\hline & \multicolumn{2}{c}{$\begin{array}{c}\text { Unstandardized } \\
\text { Coefficients }\end{array}$} & $\begin{array}{c}\text { Standardized } \\
\text { Coefficients }\end{array}$ & t & \multirow{2}{*}{ Sig. } \\
\cline { 2 - 5 } Model & B & Std. Error & Beta & & \\
\hline (Constant) & 11.193 & 3.349 & & 3.342 & .001 \\
brand ambassador & .196 & .082 & .210 & 2.390 & .019 \\
kualitas produk & .288 & .064 & .396 & 4.502 & .000 \\
\hline
\end{tabular}

a. Dependent Variable: minat beli

R-Square : 0,215

Adjusted R Square : 0,199

Diketahui $R$ Squaresenilai 0,215

$$
Z=0,210 X_{1}+0,396 X_{2}+0,886
$$

Maka $=\sqrt{1-0,215}=0,886$. Jadi

$$
Z=\rho_{Z X 1} X_{1}+\rho_{Z X 2} X_{2}+\varepsilon_{1}
$$

\begin{tabular}{|c|c|c|c|c|c|}
\hline \multirow[b]{2}{*}{ Model } & \multicolumn{2}{|c|}{$\begin{array}{c}\text { Unstandardized } \\
\text { Coefficients }\end{array}$} & \multirow{2}{*}{$\begin{array}{c}\text { Standardized } \\
\text { Coefficients } \\
\text { Beta }\end{array}$} & \multirow[b]{2}{*}{$\mathrm{t}$} & \multirow[b]{2}{*}{ Sig. } \\
\hline & $\mathrm{B}$ & Std. Error & & & \\
\hline 1 (Constant) & 15.310 & 4.933 & & 3.104 & .002 \\
\hline brand ambassador & .449 & .118 & .319 & 3.803 & .000 \\
\hline kualitas produk & .143 & .098 & .131 & 1.463 & .146 \\
\hline minat beli & .518 & .138 & .343 & 3.743 & .000 \\
\hline
\end{tabular}

Tabel 7 Coefficients Sub Struktural II

Diketahui $R$ Squaresenilai 0,333

Maka $=\sqrt{1-0,333}=0,816$

\section{Uji Parsial (Uji t)}

Jadi

Hasil uji hipotesis secara parsial dari

$\mathrm{Y}=\rho_{\mathrm{YX} 1} \mathrm{X}_{1}+\rho_{\mathrm{YX} 2} \mathrm{X}_{2}+\rho_{\mathrm{YZZ}}+\varepsilon_{2}$ persamanaan sub-struktural I dan II

$\mathrm{Y}=0,319 \mathrm{X} 1+0,131 \mathrm{X} 2+0,343 Z+$ pada disajikan pada Tabel 8.

0,816

Tabel 8 Rangkuman uji Hipoteis sub-struktural Idan sub-struktural II

\begin{tabular}{|c|c|c|c|c|c|}
\hline Variabel & $\begin{array}{c}\text { Koefisien } \\
\text { Jalur }\end{array}$ & $\begin{array}{c}\text { T } \\
\text { hitung }\end{array}$ & T tabel & Sig & Keterangan \\
\hline $\mathrm{X}_{1} \rightarrow \mathrm{Z}$ & 0,210 & 2,390 & 1,983 & 0,019 & Signifikan \\
\hline $\mathrm{X}_{2} \rightarrow \mathrm{Z}$ & 0,396 & 4,502 & 1,983 & 0,000 & Signifikan \\
\hline
\end{tabular}




\begin{tabular}{|c|c|c|c|c|c|}
\hline $\mathrm{X}_{1} \rightarrow \mathrm{Y}$ & 0,319 & 3,803 & 1,983 & 0,000 & Signifikan \\
\hline $\mathrm{X}_{2} \rightarrow \mathrm{Y}$ & 0,131 & 1,463 & 1,983 & 0,146 & Tidak signifikan \\
\hline $\mathrm{Z} \rightarrow \mathrm{Y}$ & 0,343 & 3,743 & 1,983 & 0,000 & Signifikan \\
\hline
\end{tabular}

Dari lima hipotesis yang yaitu pengaruh kualitas produk dianalisis, empat diantaranya terhadap keputusan pembelian. bepengaruh positif dan signifikan Selanjutnya pengaruh langsung dan dan hanya satu yang tidak tidak langsung dan total disajikan berpengaruh dan tidak signifikan pada Tabel 9.

Tabel 9 Pengaruh Langsung, Tidak Langsung dan Total

\begin{tabular}{cccc}
\hline Variabel & $\begin{array}{c}\text { Pengaruh } \\
\text { Langsung }\end{array}$ & $\begin{array}{c}\text { Pengaruh Tidak } \\
\text { Langsung } \\
\text { (Melalui Z) }\end{array}$ & $\begin{array}{c}\text { Pengaruh } \\
\text { Total }\end{array}$ \\
\hline $\mathrm{X}_{1} \rightarrow \mathrm{Z}$ & 0,210 & & 0,210 \\
$\mathrm{X}_{2} \rightarrow \mathrm{Z}$ & 0,396 & & 0,396 \\
$\mathrm{X}_{1} \rightarrow \mathrm{Y}$ & 0,319 & 0,07 & 0,386 \\
$\mathrm{X}_{2} \rightarrow \mathrm{Y}$ & 0,131 & 0,14 & 0,271 \\
$\mathrm{Z} \rightarrow \mathrm{Y}$ & 0,343 & & 0,343 \\
\hline
\end{tabular}


Berdasarkan Tabel 9 dapat diketahui pengaruh langsung dan pengauh tidak langsung.

\section{Pengaruh Brand Ambassador terhadap Minat Beli}

Pengaruh Langsung

Brand Ambassador berpengaruh langsung positif terhadap minat beli sebesar 0,210 atau sebesar $21 \%$. Brand ambassador dan minat beli memiliki hubungan searah dimana penggunaan brand ambassador akan menarik minat membeli konsumen.

\section{Pengaruh Kualitas Produk terhadap Minat Beli}

Pengaruh Langsung

Kualitas produk berpengaruh langsung positif terhadap minat beli sebesar 0,396 atau sebesar $39,6 \%$. Kualitas produk dan minat beli memiliki hubungan searah dimana ketika suatu produk mempunyai kualitas yang baik maka akan menarik minat membeli konsumen terhadap produk tersebut.

\section{Pengaruh Brand Ambassador} terhadap Keputusan Pembelian

a. Pengaruh Langsung

Brand Ambassador berpengaruh langsung positif terhadap keputusan pembelian sebesar 0,319 atau sebesar 31,9\%. Brand ambassador dan keputusan pembelian memiliki hubungan searah dimana penggunaan brand ambassador akan membuat konsumen melakukan keputusan untuk membeli produk.

b. Pengaruh Tidak Langsung
NIAGAWAN Vol 8 No 3 November 2019 Minat beli (Z) memiliki pengaruh tidak langsung atau memiliki peran mediasi pada pengaruh brand ambassadorterhadap keputusan pembelian. Peran mediasi minat beli positif dan signifikan. Besarnya peran mediasi sebesar 0,07 atau sebesar 7\%. Hasil ini diperoleh dari perkalian koefisien jalur $\mathrm{X}_{1}$ terhadap $\mathrm{Z}$ dan $\mathrm{Z}$ terhadap Y yakni $0,210 \times 0,343=0,07$ atau $7 \%$.

c. Pengaruh Total

Pengaruh total adalah penjumlahan pengaruh langsung dan tidak langsung. Dari tabel diatas memumjukkan bahwa total pengaruh brand ambaasador terhadap keputusan pembelian sebesar 0,386 atau $38,6 \%$.

\section{Pengaruh kualitas produk} terhadap Keputusan Pembelian

a. Pengaruh Langsung

Kualitas produk berpengaruh langsung positif tetapi tidak signifikan terhadap keputusan pembelian sebesar 0,131 atau sebesar $13,1 \%$.

b. Pengaruh Tidak Langsung

Peran mediasi atau pengaruh tidak langsun minat beli pada kualitas produk terhadap keputusan pembelian sebesar 0,13 atau sebesar 13\%. Hasil ini perkalian koefisien jalur $\mathrm{X}_{2}$ terhadap $\mathrm{Z}$ dan $\mathrm{Z}$ terhadap Y yakni 0,396 x 0,343= 0,14 atau $14 \%$.

c. Pengaruh Total

Pengaruh total adalah penjumlahan pengaruh langsung dan tidak 
NIAGAWAN Vol 8 No 3 November 2019

langsung. Dari Tabel 9 menunjukkan bahwa total pengaruh kualitas produk terhadap keputusan pembelian sebesar 0,271 atau $27,1 \%$.

5. Pengaruh Minat Beli terhadap Keputusan Pembelian

Minat beli berpengaruh positif dan signifikan terhadap keputusan pembelian sebesar 0,343 atau sebesar $34,3 \%$. Minat beli dan keputusan pembelian memiliki hubungan searah dimana minat beli yang tinggi dari konsumen akan berdampak kepada keputusannya dalam membeli suatu produk.

\section{PEMBAHASAN}

\section{Pengaruh Brand Ambassador terhadap Minat Beli}

Pada penelitian ini diketahui bahwa variabel brand ambassador memiliki pengaruh positif dan signifikan terhadap minat beli. Hal ini berarti bahwa munculnya minat membeli produk Medan Napoleon dipengaruhi atau dibentuk oleh adanya brand ambassador yang digunakan oleh Medan Napoleon untuk menarik minat konsumen. Kotler (2002) menyatakan konsumen sebelum memutuskan membeli produk atau jasa, biasanya melalui tahapan; (1) pengenalan masalah, (2) pencarian informasi, (3) evaluasi, (4) kepetusan membeli atau tidak, dan 5) perilaku pasca pembelian. Pengambilan keputusan pembelian konsumen merupakan suatu proses pemilihan satu dari berbagai alternatif. Konsumen akan mengevaluasi dari berbagai produk yang ada di pasar sebelum menetapkan produk/jasa yang dibeli.
Penggunaan brand ambassador akan membantu konsumen menentukan pilihan. Karena brand ambassador biasanya menggunakan artis terkenal dimana artis selalu memperhatikan produk yang digunakan adalah produk yang bagus sehingga konsumen mempersepsikan apa yang dipakai atau dibeli artis tersebut juga bagus dana akan menimbulkan minat konsumen untuk membelinya.

Hasil penelitian ini mendukung penelitian yang dilakukan oleh Cece I. S. (2015) yang menyatakan bahwa variabel brand ambassador berpengaruh secara signifikan terhadap minat membeli konsumen. Oleh sebab itu, penting disadari bahwa brand ambassador menjadi hal yang cukup penting bagi suatu perusahaan untuk memasarkan sebuah produk serta menarik minat membeli. Konsumen di kota Medan sudah memiliki kesadaran akan berbagai macam produk dan merek yang ada. Adanya informasi dari kelompok referensi dan kemudahan mengakses informasi dari internet ataupun sosial media membuat konsumen dengan mudah mengetahui dan mengenal secara lengkap sebuah produk atau merek. Sehingga ikon dari suatu produkpun dapat diketahui dengan cepat salah satunya penggunaan brand ambassador oleh Medan Napoleon ini. Konsumen mampu membedakan mana merek yang memiliki kualitas yang baik maupun yang tidak.

\section{Pengaruh Kualitas Produk terhadap Minat Beli}

Hasil penelitian berikutnya menunjukkan bahwa variabel kualitas produk memiliki pengaruh yang positif dan signifikan terhadap variabel minat beli. Hal ini mendukung penelitian yang 
dilakukan oleh Marchelyno, dkk. (2014) bahwa variabel kualitas produk berpengaruh positif dan signifikan terhadap minat beli. Chinomona, R., Okoumba, L., \& Pooe, D. (2013) juga mengatakan bahwa kualitas gadgets dapat mempengaruhi minat beli mahasiswa.

Hasil riset ini semakin menegaskan pentingnya kualitas produk. Menawarkan produk berkualitas akan memudahkan tugas marketing menjual produk, karena produk yang kualitas bagus akan selalu dicari konsumen dan memunculkan keinginan untuk membelinya. Penelitian memberikan rekomendasi teroretis bahwa untuk menciptakan minat beli konsumen dapat dilakukan dengan membuat produk berkualitas. Persaingan bisnis kue yang sangat ketat saat ini membuat konsumen bebas memilih kue dari toko mana yang akan dibeli. Konsumen akan menjatuhkan pilihan pada toko yang menjual produk yang dianggap berkualitas.

Berdasarkan hasil penelitian menunjukkan bahwa minat beli konsumen Medan Napoleon dapat dipengaruhi oleh kualitas produk, berarti produk kue Medan Napoleon dipersepsikan konsumen memiliki kualitas produk yang bagus. Dengan demikian, apabila Medan Napoleon ingin meningkatkan minat beli konsumen maka perlu meningkatkan kualitas produk dengan memperbaiki yang masih kurang dan mempertahankan yang sudah baik.

\section{Pengaruh Brand Ambassador terhadap Keputusan Pembelian}

Hasil penelitian selanjutnya menunjukkan bahwa variabel brand ambassador memiliki pengaruh yang positif dan signifikan terhadap variabel
NIAGAWAN Vol 8 No 3 November 2019 keputusan pembelian. Ini mendukung penelitian yang dilakukan oleh Sagia, A., Situmorang, S. H., \& SE, M. (2018); Mastan, S. A. (2016) ; Putra,dkk (2014); Magdalena, P. A. (2015) menyatakan bahwa brand ambassador memiliki pengaruh yang signifikan terhadap keputusan pembelian. Yusiana, R., \& Maulida, R. (2015) menyatakan brand ambassador mempengaruhi keputusan pembelian sebesar $32 \%$.

Penggunaan artis Irwansyah sebagai brand ambassador pada Medan napoleon berhasil mempengauhi minat konsumen dan selanjutnya melakukan pembelian. Brand ambassador diharapkan dapat mewakili keinginan dan kebutuhan calon konsumen serta mampu memberikan citra positif untuk merek suatu produk dan citra positif untuk perusahaan.

Hasil riset ini menguatkan kajian teori yang menyatakan bahwa salah satu proses sebelum memutuskan membeli atau tidak melaui proses evaluasi atas bebagai altenatif. Tahap evaluasi disini dibantu oleh brand ambassador artis yang mampu membangunan citra positif untuk produk. Konsumen yang memiliki keraguan akan membeli produk Medan Napoleon sekarang memutuskan membeli karena artis terkenal juga menggunakan produk kue Medan Napoleon.

\section{Pengaruh Kualitas Produk terhadap Keputusan Pembelian}

Hasil yang diperoleh variabel kualitas produk tidak berpengaruh terhadap keputusan pembelian. Hasil ini berlawanan dengan penelitian Owusu Alfret (2013) dimana kualitas produk memiliki pengaruh yang signifikan terhadap keputusan pembelian. di mana 
kualitas produk menjadi salah satu aspek konsumen dalam mempertimbangkan pengambilan keputusan pembelian. Kualitas yang baik akan berujung pada kepuasan konsumen yang selanjutnya akan membuat konsumen tersebut menjadi loyal terhadap produk tersebut. Namun, penelitian oleh Novik krisnawati dan Mahmud (2013) menyatakan bahwa Kualitas produk tidak berpengaruh terhadap keputusan pembelian. Begitu juga penelitian yang dilakukan oleh Rumondor, P. W., Tumbel, A. L., \& Ogi, I. W. (2017). juga menyatakan bahwa kualitas produk tidak berpengaruh terhadap keputusan pembelian.

Hal ini menunjukkan bahwa konsumen Medan Napoleon tidak serta merta melihat kualitas produknya untuk memutuskan membeli produk, bisa saja keputusan pembelian dilatar belakangi oleh brand ambassador yang ditampilkan, dan juga trend oleh-oleh artis sehingga konsumen tertarik untuk membeli tanpa begitu memperhatikan kualitasnya terlebih dahulu. Kemungkinan lain, konsumen mempersepsikan bahwa produk yang sudah terkenal akan diiringi oleh kualitas yang baik. Kotler P. (2003:202) menyatakan perilaku pembelian konsumen dipengaruhi faktor persepsi, dimana jika konsumen persepsinya baik terhadap sesuatu, maka ia akan termotivasi untuk melakukan tindakan.

\section{Pengaruh Minat Beli terhadap Keputusan Pembelian}

Variabel minat beli berpengaruh positif dan signifikan terhadap variabel keputusan pembelian. Hal ini sejalan dengan penelitian yang dilakukan oleh Riska Stephani, dkk (2014) bahwa variabel
NIAGAWAN Vol 8 No 3 November 2019 minat beli berpengaruh positif dan signifikan terhadap variabel keputusan pembelian. Artinya disini adalah semakin tinggi minat membeli, maka akan mengakibatkan keputusan pembelian juga semakin tinggi. Menurut Shimp dalam Endhar (2016) bahwa pada tahapan timbulnya minat, konsumen menyadari bahwa mereka menyukai produk tertentu dan ingin memiliki produk tersebut sehingga apabila keyakinan terhadap suatu produk positif maka akan menimbulkan keputusan untuk melakukan pembelian. Hasilnya menunjukkan bahwa minat merupakan faktor yang penting dalam proses pengambilan keputusan konsumen untuk membeli produk Medan Napoleon.

Hasil penelitian selanjutnya menjelaskan bahwa brand ambassador mempunyai pengaruh tidak langsung terhadap keputusan pembelian sebesar $7 \%$. Juga kualitas produk mempunyai pengaruh tidak langsung terhadap keputusan pembelian sebesar $13 \%$.

\section{Peran Mediasi Minat Beli}

Variabel minat beli secara langsung terbukti berpengaruh positif dan signifikan terhadap keputusan pembelian. Disamping itu, terbukti memiliki peran mediasi pada pengaruh brand ambassador terhadap keputusan pembelian sebesar 7\%. Minat beli secara tidak langsung meningkatkan keputusan pembelian konsumen produk Medan Napoleon. Peran mediasi minat beli pada pengaruh kualitas produk terhadap keputusan pembelian lebih bermakna karena pengaruh langsung kualitas produk terhadap keputusan pembelian tidak terbukti berpengaruh secara signifikan. Pada kasus penelitian ini keputusan pembelian konsumen terhadap produk 
Medan Napoleon lebih dipengaruhi minat beli.

\section{KESIMPULAN}

Brand Ambassador memiliki pengaruh yang positif dan signifikan sebesar 21\% terhadap Minat Beli Medan Napoleon. Kualitas Produk memiliki pengaruh positif dan signifikan sebesar 39,6\% terhadap Minat Beli. Brand Ambassador memiliki pengaruh positif dan signifikan sebesar $31,9 \%$ terhadap Keputusan Pembelian. Akan tetapi Kualitas Produk tidak berpengaruh signifikan terhadap keputusan pembelian. Sementara Minat Beli memiliki pengaruh positif dan signifikan sebesar 34,3\% terhadap Keputusan Pembelian.

Minat beli terbukti memiliki peran mediasi sebesar $7 \%$ pada pengaruh brand ambassador terhadap keputusan pembelian. Peran mediasi minat beli semakin penting pada pengaruh kualitas produk terhadap keputusan pembelian karena kualitas tidak terbukti berpengaruh signifikan terhadap keputusan pembelian. Besarnya peran mediasi minat sebesar 14\%. Pada kasus toko kue Medan Napolen kualitas produk tidak menjadi bahan pertimbangan bagi konsumen. Keputusan pembelian lebih didominasi minat beli konsumen dari pada kualitas produk.

Salah satu cara yang dapat digunakan untuk meningkatkan omset penjalan bisnis kue adalah menggunakan brand ambassardor, akan tetapi tetap mempertimbangkan aspek biaya yang dikeluarkan untuk membayar Brand Ambassador dibandingkan dengan peningkatan omset penjualan. Toko kue Medan Napoleon diharapkan memperhatian kualitas produk yang dijual
NIAGAWAN Vol 8 No 3 November 2019 agar menjadi dasar yang penting bagi konsumen membeli. Kualitas produk Medan Napoleon masih perlu ditingkatkan misalnya dalam kerapihan kue ketikan dipotong. Kualitas juga dapat ditingkatkan dengan mengembangkan bahan, rasa, varian, bentuk, maupun tampilan yang ada serta didukung konsistensi layanan yang ada sehingga akan menciptakan kesan positif dibenak konsumen dan akan terus diingat oleh konsumen.

Peneliti yang tertarik pada bisnis kue perlu mengkaji faktor gaya hidup karena ada kalanya orang membeli kue karena ikut trend. Disamping itu, juga perlu meneliti beberapa bisnis kue yang menggunakan brand ambassador untuk memperkuat hasil penelitian.

\section{REFERENSI}

Cece, I. S. (2015). Pengaruh Brand Origin, Brand Ambassador dan Brand Image Terhadap Minat Beli Sepatu Macbeth di Sogo Galaxy Mall Surabaya. Manajemen Kinerja, 1(2), 101-110.

Chinomona, R., Okoumba, L., \& Pooe, D. (2013). The impact of product quality on perceived value, trust and students' intention to purchase electronic gadgets. Mediterranean Journal of Social Sciences, 4(14), 463.

Danang, Sunyoto. 2014. Konsep Dasar Riset Pemasaran \& Perilaku Konsumen. Yogyakarta : CAPS.

Ferdinand, A. (2002). Structural equation modeling dalam penelitian manajemen. Semarang: Badan Penerbit Universitas Diponegoro.

Fiani, S. Margaretha dan Edwin Japarianto. (2012).“Analisa Pengaruh Food Quality dan Brand Image terhadap Keputusan Pembelian Roti Kecik Toko Roti Ganep's di Kota Solo". Jurnal Manajemen Pemasaran, 1(1), 1-6. 
p-ISSN : 2301-7775

e-ISSN : 2579-8014

Hafilah, E., Chaer, V., \& Usman, O. (2019). The Effect of Brand Ambassador, Brand Image, Product Quality, and Price on Purchase Decisions Samsung Smartphones. Brand Image, Product Quality, and Price on Purchase Decisions Samsung Smartphones (January 11, 2019).

Kotler dan Amstrong. 2008. Prinsip-prinsip Pemasaran. Edisi 12 Jilid I. Jakarta:Erlangga.

Kotler dan Keller, 2007. Manajemen Pemasaran. Edisi 12, Jilid 1. Jakarta: Indeks

Kotler dan Keller. 2009. Manajemen Pemasaran I. Edisi 13. Jakarta :Erlangga.

Lea-Greenwood, Gaynor. 2012. Fashion Marketing Communications. E-Book. Somerset, NJ,USA

Magdalena, P. A. (2015). Pengaruh Brand Ambassador Terhadap International Brand Image Serta Dampaknya Terhadap Keputusan Pembelian (Studi Pada Pengguna Smartphone Samsung). Jurnal Administrasi Bisnis, 23(1).

Mastan, S. A. (2016). DEVELOPING AN ACTIVE LEARNING MODEL: CASE STUDY IN HIGHER EDUCATION.

Mowen, J. C., \& Michael, S. (2002). Minor. SM.(2002). Perilaku Konsumen Edisi Kelima Jilid, 2.

Novik Krisnawati dan Mahmud. 2013. "Pengaruh Kualitas Produk, Harga, dan Pelayanan terhadap Loyalitas Konsumen dengan Keputusan Pembelian sebagai Variabel Intervening (Studi Pada Pengguna Sepatu Bata Di Malang). Jurnal EMBA.

Owusu, Alfred. 2013 "Influences of Price and Quality on Consumer Purchase of Mobile Phone in the Kumasi Metropolis in Ghana A Comparative Study". European Journal of Business and Management. 5(1). ISSN: 22227807.

Potter, N.N. dan J.H. Hotchkiss. (1995). Food Scince (3th ed). New Delhi: CBS Publishers and Distributors.
NIAGAWAN Vol 8 No 3 November 2019

Putra, M. I. (2014). Pengaruh Brand Ambassador Terhadap Brand Image Serta Dampaknya Terhadap Keputusan Pembelian (Survey Pada Pengguna Line Di Asia). Jurnal Administrasi Bisnis, 12(1).

Riska, Stephani, dkk. 2014. "Pengaruh Green Marketing, Pengetahuan dan Minat membeli Terhadap Keputusan Pembelian". Jurnal Manajemen Teknologi. 13(2). ISSN: 1412-1700.

Rumondor, P. W., Tumbel, A. L., \& Ogi, I. W. (2017). Pengaruh Kualitas Produk, Harga, Dan Word of Mouth Terhadap Keputusan Pembelian Pada Rumah Kopi Dan Mie Toronata Di Kawangkoan. Jurnal EMBA: Jurnal Riset Ekonomi, Manajemen, Bisnis dan Akuntansi, 5(2).

Sagia, A., Situmorang, S. H., \& SE, M. (2018). Pengaruh Brand Ambassador, Brand Personality Dan Korean Wave Terhadap Keputusan Pembelian Produk Nature Republic Aloe Vera. Jurnal Manajemen dan Bisnis Indonesia, 5(2), 286-298.

Saidani, B., \& Arifin, S. (2012). Pengaruh kualitas produk dan kualitas layanan terhadap kepuasan konsumen dan minat beli pada ranch market. JRMSIJurnal Riset Manajemen Sains Indonesia, 3(1), 1-22.

Septifani, R., Achmadi, F., \& Santoso, I. (2014). Pengaruh green marketing, pengetahuan dan minat membeli terhadap keputusan pembelian. Jurnal Manajemen Teknologi,13(2), 201218.

Silviana, W., \& Hutasuhut, S. (2017) Pengaruh Harga, Lokasi Penjualan dan Kualitas Produk Terhadap Keputusan Pembelian Dodol. Jurnal PLANS: Penelitian IImu Manajemen dan Bisnis, 12(2), 164-174.

Trihendrawan N. (2018) Sektor Kuliner Indonesia Tumbuh 12,7\%; https://ekbis.sindonews.com/read/13 88028/34/sektor-kuliner-indonesiatumbuh-127-1552972400.diakses 27 November 2019.

Yusiana, R., \& Maulida, R. (2015). Pengaruh Gita Gutawa Sebagai Brand Ambassador Pond's Dalam 
p-ISSN : 2301-7775

e-ISSN : 2579-8014

NIAGAWAN Vol 8 No 3 November 2019

Mempengaruhi Keputusan Pembelian

(Studi Kasus Pada Mahasiswi

Universitas Telkom Jurusan D3

Manajemen Pemasaran). Jurnal

Ecodemica: Jurnal Ekonomi,

Manajemen, dan Bisnis, 3(1), 311-316.

(2018).Tahun 2018, industri makanan

minuman diperkirakan tumbuh $10 \%$

diakses 28 November 2019

https://industri.kontan.co.-

id/news/tahun-2018-industri-makanan-

minuman-diperkirakan-tumbuh-10

(2019) Sempurnakan Peluang Bisnis

dengan Alat yang Menunjang,online ;

https://www.radarbandung.id/ekbis/-

2019/11/13/sempurnakan-peluang-

bisnis-dengan-alat-yang-menunjang/,

diakses, 28 November 2019 